For citation: Ekonomika regiona [Economy of Region]. - 2016. — Vol. 12, Issue 4. - pp. 1263-1273

doi $10.17059 / 2016-4-26$

УДК 336.76

S. U. Niyazbekova a), I. E. Grekov ${ }^{\text {b) }}$,T. K. Blokhina ${ }^{\text {a) }}$

a) Peoples Friendship University of Russia (Moscow, Russian Federation; e-mail: shakizada.niyazbekova@gmail.com)

b) Orel State University named after I. S. Turgenev (Orel, Russian Federation)

\title{
THE INFLUENCE OF MACROECONOMIC FACTORS TO THE DYNAMICS OF STOCK EXCHANGE IN THE REPUBLIC OF KAZAKHSTAN
}

This article describes the influence of macroeconomic factors on Kazakhstan Stock Exchange Market by using data from 2005 to 2014. Engle-Granger cointegration test has shown that stock index is cointegrated with the exchange rate, interest rate, CPI and oil price. Vector error correction model has confirmed that macroeconomic variables and the stock index has a long-term equilibrium relationship. Moreover, empirical results have shown that stock index can be used as a leading indicator of the economic situation in Kazakhstan. Therefore, the authors decided to consider the impact of major macroeconomic indicators to the dynamics of the stock market of the Republic of Kazakhstan. The Engle-Granger cointegration test results show that the following variables such as exchange rate, 10-years long-term bond rate, the consumer price index and the Brent oil price are cointegrated with stock index, which means that there is a long-term relationship between this stock market index and these variables. With the help of econometric models, the authors have found the factors such as the exchange rate, the 10-year long-term bonds rate, the consumer price index and the Brent oil price (these factors have the long-term relationship with stock market index). Changes in the dynamics of the stock market index in Kazakhstan are caused by changes in the dynamics of Central bank's reserves and export. The analysis has shown that the economy of the Republic of Kazakhstan (the index reflects the situation in the real sector of the economy) remains dependent on world oil prices, the volume of exports and the rate of the national currency.

Keywords: bank, capital, economic, finance, money, stock, index, market, price, value, effect, balance

\section{Introduction}

In recent years, in post-Soviet countries, there is active work on the development of stock markets, as one of the most important mechanisms for the flow of capital. It can be seen or assumed that in the post-Soviet countries with raw oriented economy, the growth of the stock market is influenced by external factors instead of internal factors. That is why we decided to consider the impact of major macroeconomic indicators to the dynamics of the stock market of the Republic of Kazakhstan as one of the post-Soviet countries.

Considering how some factors may affect the asset price, it would be logical to assume that there are specific ways on which this factors can operate. The price of any asset can be evaluated through dividend discount model (DDM), which had been proposed by Miller and Modigliani [1]. According to the idea of this model, the price of any asset as well as stock price is equal to the present value of future cash flows of the asset (stock, bond). As an asset is stream of cash flows from business perspective and value of an asset equals to the value of stream of cash flows,

\footnotetext{
1 @ Niyazbekova S. U., Grekov I. E., Blokhina T. K. Text. 2016.
}

$$
P=\sum \frac{E_{t}(C)}{(1+r)^{t}},
$$

where $t E_{t}(C)$ - expected cash flows of an asset in period; $1 /(1+r)^{t}-$ discount factor at the $t$ period; $r<1-$ discount rate.

Changes of asset (stock, bond and other assets) price is a combination of changes in expected future cash flows and discount rates

$$
\frac{d P}{P}=\frac{d E(C)}{E(C)}-\frac{d(1+r)}{1+r} .
$$

A number of empirical studies inform that the impact of all factors somehow affects to the expected future cash flows or discount rate. According to these empirical studies, there is a relationship between macroeconomic variables and changes in assets prices or equity market returns.

\section{Literature review}

\subsection{Industrial production index}

Industrial production index $(I P)$, is the index of real production output. According to the empirical studies with monthly data, industrial production has been often used instead of GDP since this indicator is available once a month, while the 
GDP data is available on a quarterly or annual basis. Growth of the industrial production index is calculated as

$$
\log \left(I P_{t+1}\right)-\log \left(I P_{t}\right),
$$

where $I P$-Index of industrial production.

Fama [2, p. 545-565, p. 1089-1108] and James $[3$, p. 1375-1384] showed that the expected growth of the industrial production index has a significant positive effect on stock prices growth. Fama (1990) [3, p. 1089-1108] revealed that the growth rate of future production output describes the variation of $6 \%$ growth in equity market prices. He notes that the past and current values of output growth rates affect the future values.

Kaul [5, p. 253-276] estimates the variation in stock returns due to expectations of future cash flows by regressing stock returns on future growth rates of real economic activity. He found that industrial production explains as much more variation as alternative real activity variables, but growth rates of real GNP and gross private investment are close competitors.

Schwert, among others, found that large fractions of annual stock return variances can be traced to forecasts of real economic variables such as real GNP and industrial production (IP) [6, p. 1237-1257]. These authors and the others have shown that the relation between stock returns and future real activity is strong. Geske and Roll have confirmed that stock returns are highly correlated with future real economic activity. These facts indicate that real economic activity really shows or explains the stock market return, on the other hand, there is an inverse relation between stock market return and economic activity that is why stock market index called a good leading indicator for future production [7, p. 1-33].

Esen Erdogan, Umit Ozlaly in the study of the impact of macroeconomic factors on the Turkey stock market showed a positive relationship between the industrial production index and stock market. The authors explained this relationship as the growth of industrial production that leads to an increase in income and cash flows of companies that have a positive trend on the stock market return [8, p. 69-90].

Luo and Visaltanachoti in their work, based on general equilibrium model proposed by them, indicated two possible channel impact of output on stock index return: demand shock and impact of relative prices [9]. The first channel operates as an increase in production of domestic goods caused by shock in demand for them is accompanied by the improvement of trade conditions with foreign markets. These improvements and growth in output generate an upward pressure on the domestic financial market. Thus, there is a positive relationship. On the other hand, the relative prices channel may lead to the opposite effect. If the release of traded goods in a foreign market is growing regarding the release of non-tradable goods, then the relative price of non-tradable goods begins to rise which will lead to increase in the exchange rate and the deterioration of trade conditions. Deteriorating conditions have downward pressure on the domestic financial market.

Tsuma in her work explored the link between the stock index and the index of industrial production and consumer prices. The author found that there is a stable relationship between industrial production and stock indices [10]. However, a sign of relationship is not defined as the different lags of the index of industrial production has different effects.

In addition, previous studies have shown a significant positive relationship between the increase in prices and the expected growth of industrial production and an insignificant link with the past performance of the industrial production.

\subsection{Exchange rate}

The study of the impact of exchange rates on the stock market returns as well as stock index price is important to the economists, international investors and politicians. Thus, as for international investors, it is due to the fact that the positive correlation between the exchange rate and stock market increases volatility in the yield, while negative relationship can eliminate the need to hedge currency risk. There have been a number of empirical studies conducted to test the relationship between stock prices and exchange rates using different techniques and databases, but the results were mixed.

Theoretically, it can be summarized that the dynamic relationship between stock prices and exchange rates is considered in two directions. On the one hand, the "flow-oriented" model of exchange rates, proposed by Dornbusch and Fischer, focuses on the current transactions account balance or trade account balance [11]. Supporters of these models claim that changes in exchange rates affect the international competitiveness, and thus affect the real income and productivity, as well as the future cash flows of the company. Thus, the depreciation of the national currency will encourage exports, which will increase the profits of companies. However, the production costs of those firms that used imported inputs will increase, resulting in lower profits of these companies. So, the impact 
of the exchange rate influences on the stock market in different directions.

On the other hand, the "stock-oriented" models of exchange rates offered by Branson and Frankel claim that innovation in the stock market affect to aggregate demand through the wealth effect and the effect of liquidity, thereby, influencing on the demand for money (Gavin.) For example, the stock price decline leads to a reduction of domestic investors' wealth, leading to a decrease in the demand for money with a consequent reduction in interest rates. Subsequently, the low-interest rates prevent capital inflows, given other conditions being equal, which leads to currency devaluation and, consequently, the dynamics of the exchange rate may be affected by changes in stock prices.

Esen Erdogan and Umit Ozlaly showed the ambiguous relationship between the exchange rate and the stock market in Turkey. So until 1994, the depreciation of national currency led to a reduction of the dynamics of the stock market, however, after that period, the connection became opposite. On the one hand, the depreciation of the national currency leads to higher prices for imported capital goods, reducing profit margins, on the other hand, increases the competitiveness of firms in international markets, which lead to an increase in stocks.

Maria Caporale, John Hunter, Menla Ali investigated the nature of the relationship between the stock market and exchange rates in the US, UK, Canada, Japan, Euro Zone and Switzerland using data from 2007 to 2010. The two-dimensional UEDCC-GARCH model showed unidirectional Granger causality, i.e. change the dynamics of the stock market led to a change in the exchange rate of the US and UK and communication in the opposite direction in Canada, as well as bi-directional causality in the Eurozone and Switzerland. The results of unsteady correlations showed that the relationship between two variables increased during the last financial crisis. The authors' conclusions indicate the limited opportunities for investors to diversify their portfolios during the crisis, due to a general drop in prices and the depreciation of currencies [12, p. 87-103]. Chen's empirical results (2011) showed that the relationship between exchange rates and stock prices in Asia also became stronger in times of crisis due to the flow of capital. During the crisis, foreign investors sell stocks, resulting in an outflow of capital and puts pressure on national currencies. In addition, Chen held a sectoral analysis of the causal link, which showed that the parallel between the dynamics of the exchange rate and export-oriented industries are not so strong. This indicates that the parallel between the dynamics of exchange rates and the Asian emerging stock markets is generally caused by the movement of capital rather than the trade balance [13, p. 383-403].

\subsection{Interest rate}

There are many theoretical studies about the impact of interest rates on the value of the stock price, and through them to the consolidated stock indexes.

Here are the main ones:

- Interest rates affect the stock price through the discounting factor (Campbell, 1987). The general level of interest rates determines the yield, which wants to receive by investing in stocks, that is - the discount rate. The value of the stocks depends on the yield to maturity rate: the higher yield, investors want to get from the ownership of stock, the less they want to buy them. Accordingly, there is a negative correlation - the lower general level of interest rates, the higher will be the stock price. Thus, the interest rate reflects the loss (profit) on alternative investments [14, p. 373-399];

- The interest rate reflects the marginal productivity of capital. The interest rate is the return on invested capital. In equilibrium, interest rate equal to the marginal productivity of capital. Consequently, the low rate indicates a low capital productivity, which affects the mood of investors and reducing the demand for the stocks, which in turn leads to lower prices;

- Interest rates determine the amount of borrowing. Low-interest rates allow companies to save, reduce borrowing costs and thus, to increase its profits, which leads to the higher prices of stocks.

Several studies have shown that interest rates and stock prices have a negative relationship. For example, Schiller and Beltrari examined whether the price movements of stocks and bond yields be explained in terms of present value models using annual data in the United States, 1871-1989, and the United Kingdom, 1918-1989. The results show that there is a negative correlation between the change in the logarithm of the actual stock prices and changes in long-term real interest rates. The Thorbecke's results show a negative relationship between the change in the federal funds rate and the yield of the shares, noting that stimulating monetary policy leads to an increase in future cash flows of the company and reduces the discount rate at which the cash flows are capitalized [15, p. 635-654]. 
On the other hand, a large number of studies show a positive relationship between interest rates and stock prices. Apergis and Eleftheriou conducted an empirical study examining the relationship between the prices of stocks, inflation and interest rates on monthly data in Greece in the period 1988-1999. The results have shown that although interest rates are positively correlated with stock prices, this relationship is not statistically significant [16, p. 231-236]. Bohl et al. studied the relationship between stock returns and short-term interest rates in Germany for the period 1985-1998. They found a positive but statistically insignificant relationship between stock returns and short-term interest rates on daily and monthly data [17, p. 719-733].

Durr and Giot explored the possibility of a long-term relationship between income, prices, stocks and interest rates, defined as the rate on long-term government bonds using the cointegration analysis for 13 countries in the period from January 1973 to December 2003. Their empirical results have shown that long-term rates on government bonds statistically significant effect on the stock market [18, p. 613-641].

\subsection{Money supply}

There are two competing hypotheses about the relationship between the money supply and stock market returns. Milton Friedman suggests that balanced investor portfolio has several types of including money. A sudden increase or decrease in the growth rate of money supply leads to an imbalance in the investment portfolio. The increase in the money supply in line with the income effect leads to the fact that investors increase demand for other assets. This hypothesis implies that the reaction of the price of other assets to the change in the money supply is shown with a certain lag. The alternative hypothesis of market efficiency (EM) suggests that all relevant information immediately and fully reflected in the market value of the stock exchange. Accordingly, the increase in money supply will immediately affect the stock market.

Sprinkel carried out the first attempt to empirically test the hypothesis of MP. Using data for 1918-1960 years, he graphically displayed the level of money supply and the dynamics of the stock market. He made a conclusion that changes in the stock market lag behind changes in the money supply [19]. Palmer updated Sprinkel's data of 1960-1969 and came to the same conclusion. EM hypothesis was first proposed by Fama [20, p. 19-22]. Subsequently, Rozeff (Rozeff), using data from 1916-1972 showed empirical evidence that static market lag effect of changes in monetary policy on stock prices almost zero. He suggests that stock prices immediately reflect changes in monetary policy and, moreover, the stock market actually provides for the future growth of the money supply [21, p. 245-302].

In the works of Homa and Jaffee, the effect of money supply on the price of shares is considered from three perspectives: the impact on dividends and their growth rate, the impact on the risk-free rate and the impact on the risk premium [22, p. 1045-1066].

The main channel of influence of money supply on dividends are current and expected corporate earnings. The decline in the money supply will lead to higher interest rates, which reduce the sensitivity to the percentage of costs (example, capital). Cost reduction will reduce the company's revenue and profits. It affects not only the current dividend but also lowers expectations for their future growth. The impact of money supply on the risk-free rate is positive. Reducing the money supply will lead to an increase in the risk-free rate and the rationing of credit rates on the borrowed funds. In turn, that will lead to an increase in the discount rate and its expected value.

The impact on the risk premium should be considered from the standpoint of the relationship to the risk of a particular investor. Risk-averse investor requires a positive risk premium, which increases with increasing uncertainty regarding future dividends. If you touch the effect of money supply on the risk premium there can be a twofold relationship. If money supply growth is not accompanied by an increase in the rate of inflation, the risk premium will decrease. However, if money growth is accompanied by rising inflation the risk premium will also increase.

Schwert, Pierce and Roley also consider the relationship between the money supply and the yield of financial assets. Authors give two possible explanations for the relationship between these parameters. The first relates to the fact that economic agents expect inflation if there is an increase in money supply. The second possible explanation is based on the fact that a change in the money supply, economic agents expects any action from the state regulator (such as the Central Bank). In particular, the growth of money supply agents can expect an increase in shortterm interest rates, aimed at reducing the attractiveness of money and curb possible inflation. Thus, changes in the profitability of financial assets are a reaction to the actions of the authorities [23, p. 3-12].

Pierce et al. have obtained the following results: 
- Stock prices only react to unexpected changes in the money supply;

- Market participants are treated as changes in the level of money supply and unexpected changes;

- The reaction of prices is symmetrical with respect to the sign of change in the money supply;

- The reaction of prices is not linear;

- The most of the reaction is shown in the first day after the announcement of news.

\subsection{Oil price}

In general, the nature of the relationship between the world oil prices and the stock market is determined by which the countries are exporter or importer. In the first case in a number of research results indicate a positive association and in the second - the negative.

The research of Chen, Roll and Ross for the US market was found that the changes in oil prices have little effect on stock prices. In later studies, the results were different [24, p.383-403]. The work of Cole and Jones were obtained to confirm the presence of the negative impact of rising oil prices on the stock market. And in addition to the US market, they considered such countries as Great Britain, Canada and Japan. They also showed that the US and Canadian markets are rational: changes in stock indexes response to changes in oil prices can be completely described by the impact of oil prices on the current and expected future real cash flows.

In the study of Kilian and Park was received the same result. They explain it this way. Higher oil prices often reflect investor concern about the future shortage of this energy. Thus, a sharp increase in the price of oil leads to the formation of the corresponding negative sentiment on the market resulting in a decrease of prices [25, p. 1267-1287]. Arora, Tyers and Akram (2009) in their works indicate a possible connection of financial assets and the price of oil. The authors believe that the rise in share price, evidence of the growth of production in general, and leads to an increase in demand for energy, particularly oil [26, p. 142-150].

Fedorova, Snyatkova and Sutyagin (2012) in their study conducted Granger's test that showed a causal relationship between the index of developing countries and oil prices. This is understandable high demand in developing countries for energy resources. Rising oil prices slow economic activity in emerging markets [27, p. 41-49]. Fedorova and K. Pankratov have tested econometric model EGARCH, to assess the impact of various factors on the Russian stock market. The analysis revealed a strong dependence of the dynamics of the
MICEX index on the oil price and the dollar exchange rate [28, p. 78-83].

Fedorova E. A. and Lazarev M. P. used the monthly data determine the impact of changes of oil prices on the stock market of the Russian Federation, which have been divided into two periods: the general and the crisis. With the help of the causal Granger's test; evaluation of the VAR model; cointegration analysis, the authors showed that oil prices have a long-term impact on the Russian stock market [29, p. 11-14].

\subsection{Inflation}

On the one hand, increased inflation may negatively affect the stock market, as the acceleration of inflation reduces the value of expected cash flows, increases the nominal interest rate, and, as a result, the discount factor. This, in turn, leads to a decrease in the stock price. On the other hand, the rise in prices increases the revenue of the company which has a positive effect on cash flows related to the shares and increases their value.

Some early articles (Fama; James) distinguish the effects of the impact of the expected and unexpected inflation on stock returns and show a statistically significant negative relationship between inflation and stock returns. Fama (1981) defined the expected inflation as

$$
i_{t}=\alpha_{t-1}+\beta T B_{t-1}+\eta_{t},
$$

where $\alpha_{t-1}$-arandomwalk, $T B_{t-1}$-continuously compounded inflation rate and the rate on shortterm bills. The calculated values $\alpha_{t-1}+\beta T B_{t-1}$ represent expected inflation, and remnants of the regression $\eta_{t},-$ an unexpected inflation.

Feldstein (1980) in their work considers inflation as a tax on corporate income, and as a factor that reduces the real depreciation. If we consider the situation of zero inflation, and then compare it with the situation in non-zero inflation, according to the author, we can draw the following conclusion. The rise in prices reduces the real value of depreciation, which consequently increases the real value of the tax base and lower real income including per share. More precisely, the impact of inflation on the demand for the stock, which is largely dependent on the price, depends on the tax rates on personal and corporate income. The author described how inflation affects the actions and showed that for the period of hyperinflation, the link between inflation and stock prices is negative. However, he stressed that for the period of sustained high inflation can be seen the growth of prices [30, p. 839-847]. Summers in its work as described above is considered "tax effect" in relation to the US data. Analysis of the data for 
Result

\begin{tabular}{|l|c|}
\hline \multicolumn{1}{|c|}{ Macroeconomic factors } & Hypothesis/ Relationship \\
\hline The price of Brent crude oil & Positive \\
\hline Industrial production & Positive \\
\hline Exchange rate & Positive \\
\hline Interest rate & Negative \\
\hline CPI & Negative \\
\hline S\&P 500 & Negative \\
\hline Central bank reserves & Positive \\
\hline Export & Positive \\
\hline Import & Negative \\
\hline M3 & Positive \\
\hline
\end{tabular}

70 years showed a significant negative relationship between inflation and the price of the shares, since in these years in the United States observed two-digit inflation, caused by the policy of reducing unemployment [31, p. 67-140]. Similarly, Bond and Webb (1995) revealed the presence of a negative relationship between inflation and the price of shares in the period of hyperinflation [32, p. 327-334].

In addition to the existence of "tax effect" should highlight the presence of another effect-"the illusion of inflation." Inflation adversely affects to the expectations regarding future cash flows, which is connected with the already mentioned tax effect, and with the planning of the nominal interest rate. This may lead to an underestimation of the shares, that is, it turns out that inflation has a negative effect on the value of shares in companies, and through them to the Composite Stock Index. Cohen and Modigliani (Modigliani, et al., 1979) hypothesized that in a period of inflation, investors underestimate the share of about $50 \%$. At the heart of this underestimation are two main reasons. The first is that investors in planning their activities do not use real and nominal interest rate, which is significantly higher [33, p. 24-44]. Second-already described the tax effect. Ritter and Warr (Ritter, et al.) have shown that this effect is actually observed in particular from 1982 to 1999 . US investors have consistently underestimated the shares [34, p. 29-61].

Hess and Lee in their work provided a brief summary of earlier conclusions regarding the relationship between stock returns and inflation. The authors, based on the facts of earlier studies (Blanchard, et al.), argue that the two situations are possible. The first situation is related to the supply shocks that are usually non-monetary in nature. In this case, inflation arises is usually negatively associated with stock returns. On the other hand, demand shocks are usually caused by monetary shocks [35, p. 1203-1218]. In this case, the link between inflation and stock returns is posi- tive. Therefore, a sign the relationship between inflation and stock returns depends on what shocks are stronger in a given time.

\section{Hypothesis}

Based on the analysis of empirical studies and the structure of the stock index KASE following hypotheses have been put forward (see Result).

\section{Research methodology}

\subsection{Unit Root Test}

In order to do time series analysis, it is required to check them for stationarity since the model results will be unreliable if series are non-stationary. A unit root test will be used to avoid spurious regression. There is a variety of tests, however, we will use the most popular one (Dickey-Fuller Test) in order to check series stationarity. Null and alternative hypotheses are as follows:

$H_{0}: \rho=1$ Unit root [Variable is not stationary];

$H_{0}: \rho<1$ No unit root [Variable is stationary].

If a coefficient markedly differs from 1 , i.e. below 1 , the hypothesis presuming y to contain a unit root is rejected. Rejection of null hypothesis means series stationarity. If we do not reject a null hypothesis, we conclude the series have a unit root. If the test shows non-stationarity of time series, the first difference will be taken.

\subsection{Granger Causality Test}

Granger causality test has been used. The statistical test is destined for determination of cause and effect relation between the variables. Particularly, the test is based on the following bivariate regressions

$$
\begin{aligned}
& V_{S, t}=\alpha_{1}+\sum \beta_{i} V_{S, t-1}+\sum \lambda_{i} V_{M . t-1}+\varepsilon_{1 t}, \\
& V_{M, t}=\alpha_{2}+\sum \theta_{i} V_{S, t-1}+\sum \varphi_{i} V_{M, t-1}+\varepsilon_{2 t},
\end{aligned}
$$

where $\varepsilon_{i}-$ stationary residuals.

Null hypothesis $-V_{M}$ is not a reason for changing. $V_{S}$ is rejected if li significantly differs from null. Possible relation of $V_{S}$ to $V_{M}$ can be also tested, by using a joint significance of $\theta_{i} s$. This can be done by standard $F$-tests. The following four results can be obtained: causality of $V_{M}$ from $V_{S}$, causality of $V_{M}$ from $V_{S}$, bidirectional causality, no causality, where $\lambda_{i} \neq 0 ; \theta_{i} \neq 0 ; \lambda_{i} \neq 0, \theta_{i} \neq 0$, respectively.

\subsection{The Engle-Granger Test}

Engle and Granger proposed a simple cointegration test that implicates least-squares fitting of regression of two integrated variables and testing of regression residuals for a unit root. So, assume that $X_{1}, \ldots, X_{n}$ are integrated variables, then 
Table 1

ADF-тест

\begin{tabular}{|c|c|c|c|c|c|c|}
\hline $\boldsymbol{p}$-value & Stock_index & Brent & CPI & EXCHRATE & YTRB & S\&P500 \\
\hline At level & 0,3865 & 0,4268 & 0,6699 & 0,9374 & 0,2343 & 0,9515 \\
\hline 1st difference & $2,947 \mathrm{e}-012$ & $9,492 \mathrm{e}-014$ & $4,382 \mathrm{e}-011$ & $3,517 \mathrm{e}-060$ & 0,03476 & $1,52 \mathrm{e}-033$ \\
\hline p-value & INDUSTRIAL & M3 & EXPORT & IMPORT & CBRESERVES \\
\hline At level & 0,8935 & 0,9968 & 0,666 & 0,7916 & 0,8564 \\
\hline 1st difference & $2,262 \mathrm{e}-007$ & 0,0005066 & $4,584 \mathrm{e}-024$ & $5,658 \mathrm{e}-013$ & $1,796 \mathrm{e}-006$ \\
\hline
\end{tabular}

$X_{1}$ is a dependent variable. Least-square fitting regression is

$$
X_{1 t}=\beta_{1}+\beta_{2} X_{2 t}+\ldots .+\beta_{n} X_{n t}+\varepsilon_{t} .
$$

The regression is called the Engle-Granger regression and Engle-Granger test is a test for the presence of unit root in regression residuals. If the test shows presence of a unit root in residuals, then the variables $X_{1}, \ldots, X_{n}$ are cointegrated with cointegration vector $\left(1,-\beta_{2}-\ldots-\beta_{n}\right)$. Put it differently,

$$
Z=X_{n}-\beta_{2} X_{2}-\ldots-\beta_{n} X_{n} .
$$

The stationary linear combination of integrated variables means a presence of long-run equilibrium. If regression residuals are non-stationary, the variables will not be cointegrated and estimation of least-square fitting will not be justifiable.

\subsection{Vector error correction model (VECM)}

In our study, we will use the Engle-Granger procedure for building error correction model. Error correction model is a multitemporal model built on the first-order differences of integrated variables. So, when series $X_{t}, Y_{t} \sim I(1)$ are contegrated

- Long-run (equilibrium) relationship model $Y_{t}=\alpha+\beta X_{t}$

- Short-run dynamics model or error correction model $(E C M)$ these models are coherent.

Engle and Granger proposed a two-step model for building ECM for cointegrated series. At the first stage, unknown parameters $\alpha$ and $\beta$ are estimated by least-square method within the regular regression model $y_{t}$ and $x_{t}$. Next, when we obtain estimated parameters $\hat{\alpha}$ and $\hat{\beta}$, we find estimated values of departure from long-run equilibrium point, i.e. estimated regression residuals are

$$
\hat{Z}=Y_{t}-\hat{\alpha}-\hat{\beta} X_{t} \text {. }
$$

At the second stage, we separately estimate the following model using least-square model:

$$
\begin{aligned}
& \Delta X_{t}=a_{1}+\sum_{i=1}^{m} \beta_{11}^{i} \Delta X_{t-i}+\sum_{i=1}^{m} \beta_{12}^{i} \Delta Y_{t-i}+\gamma_{1} Z_{t-1}+\varepsilon_{1 t}, \\
& \Delta Y_{t}=a_{2}+\sum_{i=1}^{m} \beta_{21}^{i} \Delta X_{t-i}+\sum_{i=1}^{m} \beta_{22}^{i} \Delta Y_{t-i}+\gamma_{2} Z_{t-1}+\varepsilon_{2 t} .
\end{aligned}
$$

Error correction model lies in the fact that model shows the way how to adjust the shortrun departures from long-run equilibrium. In the model above, $Z$ is a recourse vector.

\section{Empirical results}

\subsection{Data description}

In this study, we used the monthly data of main macroeconomic indicators such as inflation, industrial production index, export, import, interest rate, exchange rate, oil prices, money supply, central bank reserves, S\&P500 and KASE stock index from January 2005 to December 2014. All data were taken from the Bloomberg and Thomson Reuters Eikon platforms. The total number of observation is 120 , which we considered as sufficient for the analysis of time series.

\subsection{Analysis}

To conduct our analysis it is necessary to test for stationarity our time series data of selected variables:

- KASE stock index (Stock_index);

- Brent Oil price (Brent);

- Consumer Price Index (CPI);

- Exchange rate (EXCHRATE);

- 10-year long-term bong (YTRB) as interest rate;

- Industrial production index (INDUSTRIAL);

- Central Bank reserves (CB RESERVES);

- Export (EXPORT);

- Import (IMPORT);

- Money supply (M3),

- US S\&P500 stock index (Table 1).

Based on stationarity test above, we were looking for the presence of a unit root in our series. The result of stationarity test shows that all the series is non-stationary. However, after taking first difference they become stationary and the null hypotheses about having a unit root is rejected. Therefore, all the series are integrated of first order, so we test for cointegration using the Engle-Granger method (Table 2). To determine the lag for cointegration test we will use the cub root of the number of observation for each series. 
Test Engle-Granger cointegration

\begin{tabular}{|c|c|c|c|c|c|c|}
\hline \multicolumn{7}{|c|}{ Engle-Granger Cointegration test (2005-2015 period) } \\
\hline \multicolumn{7}{|c|}{$\begin{array}{l}\text { Algorithm: equation: STOCK_INDEX }(t)=\alpha+\beta\left(i \_ \text {factor }\right)(t)+u(t) \text {. } \\
\text { we get the residual of the equation: } u \_h a t(t)=\operatorname{STOCK} \text { INDEX }\left(t-\hat{\alpha}-\hat{\beta}\left(i \_ \text {factor }\right)(t)\right. \\
\text { after that we check the equation } \Delta u \_ \text {hat }(t)=\varphi u_{t-1}+\theta u_{t-1}+\zeta_{t} \text { to the presence of unit root } H_{i}: \varphi=1 \\
\text { without constant and trend }\end{array}$} \\
\hline \multicolumn{2}{|c|}{ Variables } & $H_{0}: \varphi=1$ & $\varphi$ & t_statistics & $\begin{array}{c}\text { P_value } \\
10 \%\end{array}$ & $\begin{array}{c}\text { Cointegrated/ } \\
\text { No cointegration }\end{array}$ \\
\hline \multirow{10}{*}{ STOCK_INDEX } & EXPORT & Rejected & $-0,0461627$ & $-1,40723$ & 0,1487 & No cointegration \\
\hline & IMPORT & Rejected & $-0,0468207$ & $-1,61178$ & 0,1006 & No cointegration \\
\hline & INDUSTRIAL & Rejected & $-0,0165552$ & $-1,0556$ & 0,2634 & No cointegration \\
\hline & CB_RESERVES & Rejected & $-0,0235813$ & $-1,35101$ & 0,1642 & No cointegration \\
\hline & EXCH_RATE & Rejected & $-0,0353227$ & $-2,0923$ & 0,03499 & Cointegration \\
\hline & M3 & Rejected & $-0,0154954$ & $-1,19775$ & 0,212 & No cointegration \\
\hline & YTRB & Rejected & $-0,0559277$ & $-2,82718$ & 0,004568 & Cointegration \\
\hline & $\mathrm{CPI}$ & Rejected & $-0,0502706$ & $-2,55029$ & 0,01043 & Cointegration \\
\hline & SP500 & Rejected & $-0,0247939$ & $-1,504$ & 0,1244 & No cointegration \\
\hline & Brent & Rejected & $-0,030785$ & $-1,81683$ & 0,06594 & Cointegration \\
\hline
\end{tabular}

The Engle-Granger cointegration test results show that the following variables such as exchange rate, 10 -years long-term bond rate, the consumer price index and the Brent oil price are cointegrated with stock index, which means that there is a long-term relationship between this stock market index and these variables.

As we determined the long-term relationship, next we will determine the short-term relationship. To check the presence of short-term relationship we will use Error Correction Model. The sign and magnitude of Error Correction coefficient indicate the direction and speed of adjustment towards long-term equilibrium. It should be negative and significant. The negative sign means that in the absence of changes in the independent variables, the deflection pattern of long-term dependency is adjusted by increasing the dependent variable. Bannerjee al. believes that a significant error correction factor is further proof of the existence of a stable long-term relationship (Table 3).

The estimated Error Correction coefficient EC (-1) for EXCH_RATE, YTRB, CPI, Brent was -0.033; $-0.0537 ;-0.05 ;-0.009$ respectively. This means that in the absence of change in other variables deviation from the long-term equilibrium model for this factors balanced by $3.3 \%, 5.4 \%, 5 \%$ and $0.9 \%$ increase in the stock index in a month. This means that returning to the long-term equilibrium model takes more than 30,16, 20, 111 and 3 months respectively. As result, a regression equation can be represented as follow:

$$
\begin{gathered}
\text { STOCK_INDEX }=0,44 \text { BRENT }+110 \mathrm{CPI}+ \\
+1,04 \mathrm{EXCH} \text { _RATE }+18,6 \mathrm{IND}- \\
-0,27 \mathrm{YTRB}-1,7 \mathrm{~S} \& \mathrm{P} 500
\end{gathered}
$$

Now we will test the series for Granger Causality test (Table 4).

Based on Granger causality test, changes in the dynamic of stock market index is caused by Brent oil price, central bank reserves and export.

However, it should be noted that the stock index is an indicator of changes in the following variables: Industrial production index, exchange rate, central bank reserves, and exports.

\section{Practical significance of the study}

Identifying the impact of macroeconomic factors on the dynamics of the stock market is important for investors, as it affects the investment yield. This analysis is conducted within the framework of one of the stage of the fundamental approaches to determining the future dynamics of the stock market. Proposed methodology allows to quantify the impact of macroeconomic factors on the stock market, and improve the accuracy of predicting the behavior of stock market indices, which is extremely important for the evaluation of investment programs. Moreover, as Granger Causality test showed KASE index can be used to predict changes in the real economy, which can help to evaluate the economic decision-making results.

\section{Conclusion}

This study can be concluded with the opinion that several macroeconomic factors which influence the dynamic of the stock market index in Kazakhstan. With the help of econometric models, we found the factors, such as the exchange rate, the 10-year long-term bonds rate, the consumer price index, the Brent oil price (these factors have 
Vector Error Correction model

Table 3

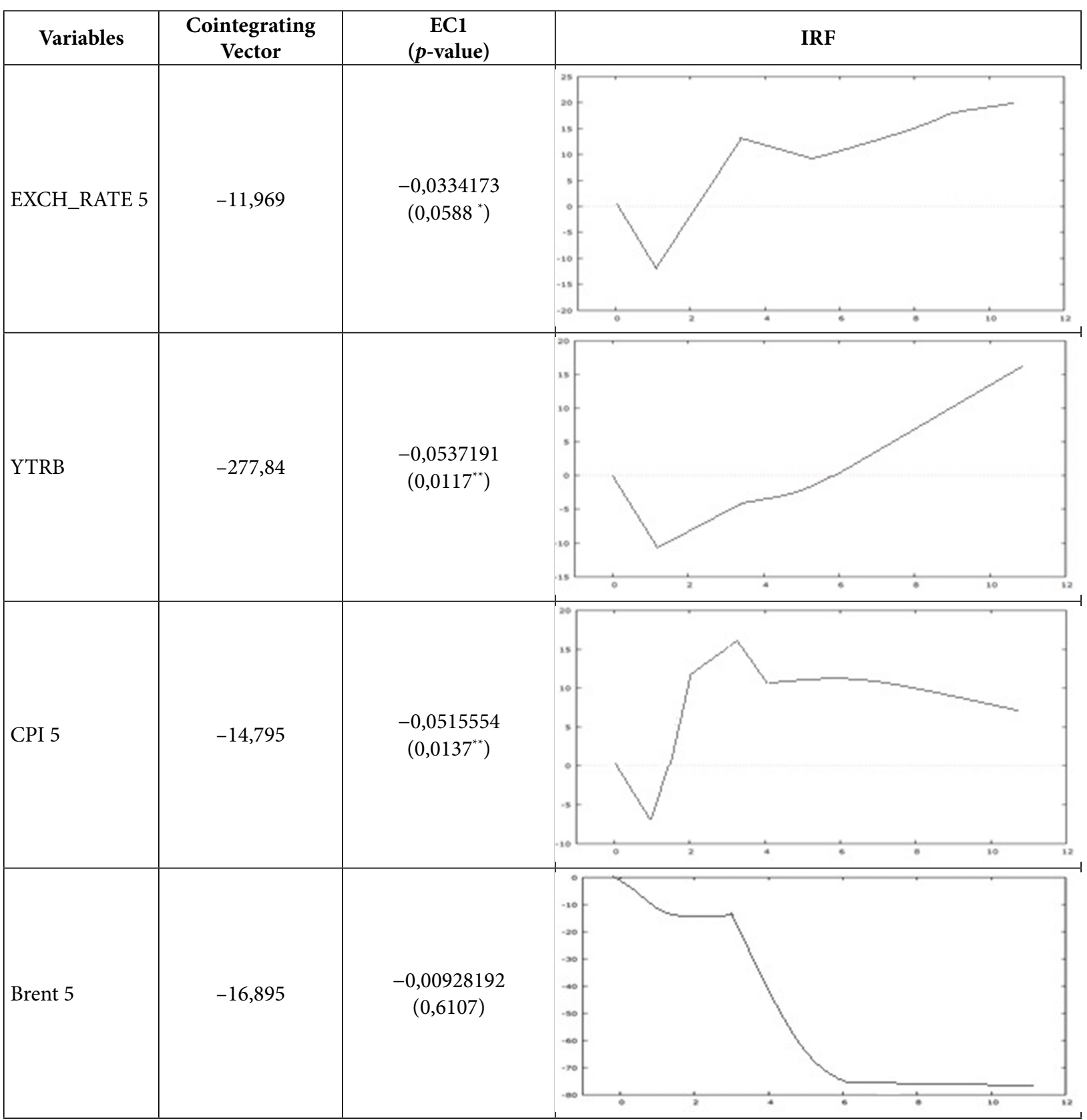

Granger causality test

\begin{tabular}{|l|l|c|c|l|}
\hline \multicolumn{1}{|c|}{ Variables } & \multicolumn{1}{|c|}{ Influence } & F-statistics & Prob. & \multicolumn{1}{c|}{ Causality at 10 \% level of significance } \\
\hline \multirow{2}{*}{ INDUSTRIAL } & Industrial to Srock_Index & 1.38818 & 0.2348 & Does not Granger Cause \\
\cline { 2 - 5 } & Srock_Index to Industrial & 2.33141 & 0.0474 & Does Granger Cause \\
\hline \multirow{2}{*}{ EXCH_RATE } & Exchange rate to Srock_Index & 1.38770 & 0.2349 & Does not Granger Cause \\
\cline { 2 - 5 } & Srock_IndextoExchange rate & 2.99116 & 0.0146 & Does Granger Cause \\
\hline \multirow{2}{*}{ YTRB } & YTRB to Srock_Index & 0.43997 & 0.8197 & Does not Granger Cause \\
\cline { 2 - 5 } & Srock_Index to YTRB & 0.43293 & 0.8247 & Does not Granger Cause \\
\hline \multirow{2}{*}{ CPI } & CPI to Srock_Index & 0.93388 & 0.4623 & Does not Granger Cause \\
\cline { 2 - 5 } & Srock_Index to CPI & 1.46636 & 0.2072 & Does not Granger Cause \\
\hline \multirow{2}{*}{ BRENT } & BRENT to Srock_Index & 3.71492 & 0.0039 & Does not Granger Cause \\
\cline { 2 - 5 } & Srock_Index to BRENT & 1.68034 & 0.1458 & Does not Granger Cause \\
\hline
\end{tabular}




\begin{tabular}{|l|l|c|c|l|}
\hline \multicolumn{1}{|c|}{ Variables } & \multicolumn{1}{|c|}{ Influence } & F-statistics & Prob. & Cable 4 \\
\hline \multirow{2}{*}{ CB RESERVES } & Reservesto Srock_Index & 2.73543 & 0.0231 & Does Granger Cause \\
\cline { 2 - 5 } & Srock_Index to Reserves & 2.90980 & 0.0169 & Does Granger Cause \\
\hline \multirow{2}{*}{ EXPORT } & Export to Srock_Index & 1.98536 & 0.0869 & Does Granger Cause \\
\cline { 2 - 5 } & Srock_Index to Export & 3.53581 & 0.0054 & Does Granger Cause \\
\hline \multirow{2}{*}{ IMPORT } & Import to Srock_Index & 1.16271 & 0.3326 & Does not Granger Cause \\
\cline { 2 - 5 } & Srock_Index to Import & 1.10408 & 0.3628 & Does not Granger Cause \\
\hline \multirow{2}{*}{ M3 } & M3 to Srock_Index & 1.50976 & 0.1931 & Does not Granger Cause \\
\cline { 2 - 5 } & Srock_Index to M3 & 0.41749 & 0.8357 & Does not Granger Cause \\
\hline
\end{tabular}

the long-term relationship with stock market index). Changes in the dynamics of the stock market index in Kazakhstan is caused by changes in the dynamic of central bank's reserves and export. The analysis shows that the economy of the Republic of Kazakhstan (the index reflects the situation in

\section{Acknowledgements}

The study has been supported by LLP "Astana School of Business and Technology".

\section{References}

1. Miller and Modigliani (1961). Retrieved from: http://www.nzfc.ac.nz/archives/2011/papers/updated/279.pdf (date of access: 17.04.2016).

2. Fama, E. F. (1981). Stock Returns, Real Activity, Inflation, and Money. The American Economic Review, 71(4), 545565.

3. Fama, E. F. (1990). Stock Returns, Expected Returns, and Real Activity. The Journal of Finance, 45(4), 1089-1108.

4. James, C., Koreisha, S. \& Partch, M. (1985). A VARMA analysis of the causal relations among stock returns, real output, and nominal interest rates. Journal of Finance, 40, 1375-1384.

5. Kaul, G. (1987). Stock returns and inflation. The Role of the Monetary Sector. Journal of Financial Economics, 18(2), 253-276.

6. Schwert, G. W. (1990). Stock returns and real activity: A century of evidence. The Journal of Finance, 45(4), $1237-1257$.

7. Geske, R. \& Roll, R. (1983). The Fiscal and Monetary Linkage between Stock Returns and Inflation. The Journal of Finance, 38(1), 1-33.

8. Erdogan, E. \& Ozlale, U. (2005): Effects of macroeconomic dynamics on stock returns: the case of the Turkish stock exchange market. Journal of economic Cooperation, 26(2), 69-90.

9. Luo and Visaltanachoti in their work (2010). Retrieved from: https://www.hse.ru/pubs/share/direct/document/63054888 (date of access: 31.01.2016).

10. Retrieved from: http://www.inesad.edu.bo/bcde2009/B3 \%20Daniel\%20Canedo.pdf (date of access: 31.03.2016).

11. Dornbusch and Fischer. Retrieved from: http://www.akes.or.kr/eng/papers(2013)/34.full.pdf (date of access: 01.04.2016).

12. Caporale, G., Hunter, J. \& Ali, F. (2014). On the linkages between stock prices and exchange rates: Evidence from the banking crisis of 2007-2010. International Review of Financial Analysis, 33, 87-103.

13. Chen, N., Roll, R. \& Ross, S. (1986). Economic forces and the stock market. Journal of business, 59(3), $383-403$.

14. Campbell, J. Y. (1987). Stock returns and the term structure. Journal of financial economics, 18(2), 373-399.

15. Thorbecke, W. (1997). On stock market returns and monetary policy. The Journal of Finance, 52(2), 635-654.

16. Apergis, N. \& Eleftheriou, S. (2002). Interest rates, inflation, and stock prices: the case of the Athens Stock Exchange. Journal of Policy Modeling, 24(3), 231-236.

17. Bohl, M. T., Siklos, P. L. \& Werner, T. (2007). Do central banks react to the stock market? The case of the Bundesbank. Journal of Banking \& Finance, 31(3), 719-733.

18. Durré, A \& Giot, P. (2007). An international analysis of earnings, stock prices and bond yields. Journal of Business Finance \& Accounting, 34(3-4), 613-641.

19. Sprinkel, B. W. (1964). Money and stock prices. Homewood, Ill: RD Irwin.

20. Palmer, M. (1970). Money supply, portfolio adjustments and stock prices. Financial Analysts Journal, 26(4), 19-22.

21. Rozeff, M. S. (1974). Money and stock prices: Market efficiency and the lag in effect of monetary policy. Journal of financial Economics, 1(3), 245-302.

22. Homa, K. E. (1971). Monetary base and stock performance. The Journal of Finance, 26(5), 1045-1066.

23. Schwert, G. W. (1983). Size and stock returns, and other empirical regularities. Journal of Financial Economics, 12(1), $3-12$. 
24. Chen, N., Roll, R. \& Ross, S. (1986). Economic forces and the stock market. Journal of business, 59(3), $383-403$.

25. Kilian, L. \& Park, C. (2009). The Impact of Oil Price Shocks on the U.S. Stock Market. International Economic Review, 50(4), 1267-1287.

26. Arora, V. \& Tyers, R. (2012). Asset Arbitrage and the Price of Oil. Economic Modelling, 29(2), 142-150.

27. Fyodorova, E. A., Snyatkova, I. N. \& Sutyagina Yu. N. (2012). Analiz zavisimosti mezhdu tsenoy na neft, valyutnym kursom i fondovymi rynkami razvivayushchikhsya stran [The analysis of dependence between an oil price, the currency rate and the stock markets of developing countries]. Daydzhest-Finansy [Digest-Finanses], (12), 41-49.

28. Fyodorova, E. A. \& Pankratov, K. A. (2009). Vliyanie mirovogo finansovogo rynka na fondovyy rynok Rossii [Impact of the world financial market on the stock market of Russia]. Audit i finansovyy analiz [Audit and financial analysis], (2), 78-83.

29. Fyodorova, E. A. \& Lazarev, M. P. (2014). Vliyanie tseny na neft na finansovyy rynok Rossii v krizisnyy period [Price influence on oil on the financial market of Russia during the crisis period]. Finansy $i$ Kredit [Finances and Credit], (2), 11-14.

30. Feldstein, M. (1980). Inflation and the Stock Market. American Economic Review, 70(5), 839-847.

31. Summers, L. H. et al. (1981). Taxation and corporate investment: A q-theory approach. Brookings Papers on Economic Activity, (1), 67-140.

32. Bond, M. \& Webb, J. (1995). Real Estate versus Financial Asset Returns and Inflation: Can a $\mathrm{P}^{\star}$ Trading Strategy Improve REIT Investment Performance? Journal of Real Estate Research, 10(3), 327-334.

33. Modigliani, F. \& Cohn, R. (1979). Inflation, rational valuation and the market. Financial Analysts Journal, 35(2), 24-44.

34. Ritter, J. R. \& Warr, R. S. (2002). The decline of inflation and the bull market of 1982-1999. Journal of Financial and Quantitative Analysis, 37(1), 29-61.

35. Hess, P. J. \& Lee, B. S. (1999). Stock returns and inflation with supply and demand disturbances. Review of Financial Studies, 12(5), 1203-1218.

\section{Authors}

Shakizada Uteulievna Niyazbekova - PhD in Economics, Senior Lecturer, Peoples' Friendship University of Russia (6, Miklukho-Maklaya St., Moscow, 117198, Russian Federation; e-mail: shakizada.niyazbekova@gmail.com).

Igor Evgenievich Grekov - Doctor of Economics, Associate Professor, Head of the Department, Orel State University named after I. S. Turgenev (29, Naugorskoe Highway, Oryol, 302020, Russian Federation; e-mail: grekov-igor@mail.ru).

Tatyana Konstantinovna Blokhina-Doctor of Economics, Professor, Department of Economics, Department of Finance and Credit, Peoples Friendship University of Russia (6, Miklukho-Maklaya St., Moscow, 117198, Russian Federation; e-mail: tk24@list.ru). 